Maciej IWAŃSKI, MA*

Legal Department

General Directorate of the State Forests

Poland
Review paper

Received: 8 October 2021

Accepted: 29 November 2021

UDK: 341.48

https://doi.org/10.47152/rkkp.59.3.3

\title{
INTERNATIONAL LAW STANDARDS REGARDING SUBSTANTIVE PETTY OFFENCES LAW***
}

This article attempts to identify and analyse, in the light of the provisions of the acts of international law, the following issues belonging to the substantive part of the law on petty offences: the general problem of criminalization in petty offenses law and; the question of the criminal nature of the law of petty offenses, and thus the application of individual provisions to it and the resulting guarantees appropriate to that law; the application of the principle of guilt on the basis of the analysed regulations as a premise for assigning liability; the principle of ne bis in idem; the principle of nullum crimen nulla poena sine lege, especially in so far as it derives from the principle of lex mitior retro agit.

Keywords: criminal law, petty offences law, human rights

\section{Introduction}

The purpose of this study is to assess whether the international law acts affect the directions and depth of possible reform of substantive petty offences law adopted in Poland. However, the result of presented analysis is much more general, as it can become an important guidance on the direction of amendments for national legislator in every State-party of analysed international law acts.

\footnotetext{
*E-mail: maciej.iwanski@lasy.gov.pl

** The work was supported by the National Science Centre, Poland, under research project „Reforma prawa wykroczeń” (,The reform of the petty offences law”), No. UMO-2016/23/B/HS5/03616.
} 
Apart from the crimes, regulated by the Penal Code of 1997, petty offences function in polish legal system, as the prohibited acts of less severe nature, punishable with penalties of less intensity, regulated by the Petty Offences Code of 1971. According to the Article $1 \S 1$ of the Petty Offences Code, petty offences liability shall be incurred only by a person who commits an act of social harmfulness, prohibited under penalty by a law in force at the time of its commission. The penalties under the petty offences code are arrest, fine and reprimand.

The aim of presented paper is to identify international-law petty offences standards and, if possible, to point out these of them which has to be adopted in domestic law to make it fully in line with international law. The scope of given remarks is limited to the 1) European Convention on Human Rights (ECHR); 2) The Charter of Fundamental Rights of the European Union (the Charter); 3) The International Covenant on Civil and Political Rights (the Covenant).

\section{Petty offences law as a criminal law}

The ECHR proclaims such fundamental principles as inter alia the presumption of innocence ("Everyone charged with a criminal offence shall be presumed innocent until proved guilty according to law" - Article 6 section 2). Furthermore, in the Article 7 section 1 expresses the nullum crimen sine lege principle, which applies to "any criminal offence" ("No one shall be held guilty of any criminal offence on account of any act or omission which did not constitute a criminal offence under national or international law at the time when it was committed. Nor shall a heavier penalty be imposed than the one that was applicable at the time the criminal offence was committed"). Likewise, in the Article 4 section 1 of the Protocol No 7. ("No one shall be liable to be tried or punished again in criminal proceedings under the jurisdiction of the same State for an offence for which he has already been finally acquitted or convicted in accordance with the law and penal procedure of that State"), the double-punishment ban (ne bis in idem) is connected with "criminal proceedings" and an "offence".

Pursuant to the Article 6 section 1 of the ECHR, in the determination of his civil rights and obligations or of any criminal charge against him, everyone is entitled to a fair and public hearing within a reasonable time by an independent and impartial tribunal established by law. It is obvious, that due to its character and functions the petty offenses law and its proceedings cannot be treated as regarding to the civil rights (however, the imposed sanctions may affect civil rights as well e.g., property). 
It is therefore crucial to examine whether the above-mentioned principles must be applied to the petty offences law. The answer to that question depends on how the terms of "criminal charges" and "criminal case", "criminal offence" is defined under the ECHR.

It needs to be emphasized that the phrase "criminal" is autonomous under the Article 6 of the ECHR. The ECtHR judges a casu ad casum, if the sanction is criminal by its nature. The applicability of the criminal aspect of Article 6 of the ECHR is based on the criteria outlined in the case of Engel and Others v. the Netherlands (as well as in subsequent judgments). These criteria are as follows: 1) classification in domestic law; 2) nature of the offence; 3 ) severity of the penalty that the person concerned risks incurring ${ }^{1}$.

According to the ECtHR it is enough to satisfy at least one of two last criteria. In other words, the second and third criteria are alternative, however the cumulative approach may be adopted where separate analysis of each one of them does not make it possible to reach a clear conclusion as to the existence of a criminal charge ${ }^{2}$. It needs to be pointed out that the ECtHR's case-law is not clear as regards the third criteria. As a rule, the sanction of imprisonment determines the criminal nature of case. With regard to the financial sanctions the ECtHR noticed that it should be considered, if it is acceptable or requested to convert uncollected fines into a term of imprisonment ${ }^{3}$.

For Article 6 of the ECHR to apply by virtue of the words "criminal charge", it suffices that the offence in question should by its nature be "criminal" from the point of view of the ECHR, or should have made the person concerned liable to a sanction which, by its nature and degree of severity, belongs in general to the "criminal" sphere ${ }^{4}$. However criminal offence referred to in the ECHR does not imply a certain degree of seriousness. As the ECtHR pointed out, it would be contrary to the object and purpose of Article 6, if the State were allowed to remove from the scope of this Article a whole category of offences merely on the ground of regarding them as petty ${ }^{5}$.

In assessing the nature of an offence, it is also important to ascertain, whether the sanctions were designed to ensure that the members of particular

1 See i.a. Engel and Others v. Netherlands, (1976, no. 5100/71, 5101/71, 5102/71, 5354/72, 5370/72), Putz v. Austria, ECtHR (1996, no. 18892/91), A. P., M. P. i T. P. v. Switzerland, ECtHR (1997, no. 19958/92); Ezeh and Connors v. The United Kingdom, ECtHR (1997, no. 39665/98, 40086/98).

2 See Lutz v. Germany, ECtHR (1987, no. 9912/82), Bendenoun v. France, ECtHR (1994, no. 12547/86); Grande Stevens and Others v. Italy, ECtHR (2014, no. 8640/10).

3 See Ravnsborg v. Sweden, ECtHR (1994, no. 14220/88).

4 See Janosevic v. Sweden, ECtHR (2002, no. 34619/97).

5 See Ozturk v. Germany, ECtHR (1984, no. 8544/79). 
groups comply with the specific rules governing their conduct or whether these rules are of general character ${ }^{6}$. In criminal cases sanctions should be imposed for the purpose that is deterrent and punitive ${ }^{7}$. It needs to be underlined that according to the ECtHR, even the relative lack of seriousness of the penalty at stake cannot divest an offence of its inherently criminal character ${ }^{8}$.

The Article 14 of the Covenant is interpreted in a similar way. It is assumed that the term "criminal case" covers all acts that are punishable under domestic criminal law. In addition, the term also refers to acts that are criminal in nature and for which sanctions are punishable, which must be considered criminal because of their purpose, nature or degree of severity, irrespective of their classification in the domestic legal order'.

Also, the CJEU refers to the jurisprudence of the ECtHR on the criteria for qualifying cases as criminal. In other words, the CJEU has not developed its own rules for assigning liability to the discussed category. According to the CJEU, three criteria are relevant for the purpose of assessing whether sanction is criminal in nature. The first criterion is the legal classification of the offence under national law, the second is the very nature of the offence, and the third is the nature and degree of severity of the penalty that the person concerned is liable to incur (Błachnio-Parzych, 2016:. 79). ${ }^{10}$

In light of the above remarks, it has to be stated that, as a rule, the responsibility for petty offences has to be considered as a criminal responsibility. In other words, the case of petty offence is a criminal case. Therefore, the guarantees regarding criminal liability must be applied to all proceedings in which abovementioned criteria are satisfied.

\section{Criminalization}

The ECHR does not directly define the way in which the contracting-states should secure the rights expressed therein. Thus, it is impossible to deduce from the ECHR the extent to which the national legislator is obliged and at the same time entitled to use instruments of widely understood criminal law, including the law of petty offenses.

6 Weber v. Switzerland, ECtHR, (1990, no.11034/84).

7 See Lutz v. Germany, ECtHR, (1987, no.9912/82); Lauko v. Slovakia, ECtHR (1998, no. 26138/95); Malige v. France, ECtHR, (1998, no. 7812/95), Zolotukhin v. Russia, ECtHR (2009, no. 14939/03).

8 See Ozturk v. Germany, ECtHR (1984, no. 8544/79).

9 See. Wieruszewski et. al, 2012: 293.

10 See C-17/10, Toshiba Corporation et al v. Úřad pro ochranu hospodářské soutěže, CJEU; (2012, no. C-17/10) Bonda, CJEU, (2012, no. C-489/10). 
The fundamental and most general directive is expressed in the Preamble to the ECHR, pursuant to which the contracting-states decided to take the first steps for the collective enforcement of certain of the rights Universal Declaration of Human Rights proclaimed by the General Assembly of the United Nations on $10^{\text {th }}$ December 1948. The Universal Declaration stipulates such rights and freedoms as: right to life, liberty and security of person (Article 3), ban on torture, cruel, inhuman or degrading treatment or punishment (Article 5), right to privacy (Article 12). Although the provisions of the ECHR expressing individual rights and freedoms do not directly refer to substantive criminal law, it is rightly pointed out that they may refer to it (van Kempen, Bemelmans, 2018: 252). It needs to be emphasized, that there is a close and obvious relationship between human rights and criminal law. The nature of such relationship should not, however, obscure its complex and paradoxical character. Abovementioned paradox lies in the fact that the criminal law appears to be both a protection and a threat for fundamental human rights and freedoms (Tulkens, 2011: 578).

It needs to be emphasized that pursuant to the ECHR nothing in it may be interpreted as implying for any State, group or person any right to engage in any activity or perform any act aimed at the destruction of any of the rights and freedoms set forth herein or at their limitation to a greater extent than is provided for in the ECHR (Article 17). The restrictions permitted under this ECHR to the said rights and freedoms shall not be applied for any purpose other than those for which they have been prescribed (Article 18). Similar provisions can be found in the Covenant (see i.e., Article 18, Article 21, Article 22).

Under the Charter, any limitation on the exercise of the rights and freedoms recognized by Charter must be provided for by law and respect the essence of those rights and freedoms. Subject to the principle of proportionality, limitations may be made only if they are necessary and genuinely meet objectives of general interest recognized by the Union or the need to protect the rights and freedoms of others (Article 52 section 1).

Article 1 of the ECHR, read together with its subsequent provisions expressing individual rights and freedoms, has to be considered as the source of negative and positive obligations of contracting-states, The fulfilment of these obligations by the state guarantees and secures the values of the ECHR. Negative obligations consist in refraining from certain actions by the state that could violate human rights and freedoms, for example by respecting the ban on torture. Positive obligations, on the other hand, consist in taking specific actions to protect rights and freedoms. Some positive obligations are expressed directly in the ECHR, such as the obligation to protect life (Article 2). As to the rights and freedoms the ECHR does not provide with the aforementioned reservation, such 
obligations are derived from the jurisprudence of the ECtHR (See e.g., Harris et. al, 2009: 94).

Boundaries between the State's positive and negative obligations under the ECHR do not lend themselves to precise definition. The applicable principles are nonetheless similar. Whether the case is analysed in terms of a positive duty of the state or in terms of interference by a public authority which needs to be justified, the criteria to be applied do not differ in substance. In both contexts one has to weigh up the fair balance between the competing interests at stake ${ }^{11}$. The limits of the fair weighing process are inter alia the essence of the right or freedom, which the legislator cannot infringe, and human dignity derived from the Article 3 of the ECHR.

In its numerous judgments, the ECtHR referred to criminal law as an effective tool to secure the observance of ECHR rights and freedoms. The ECtHR pointed out that the first sentence of Article 2 section 1 enjoins the State not only to refrain from the intentional and unlawful taking of life, but also to take appropriate steps to safeguard the lives of those within its jurisdiction, including the effective prevention and fight against crime ${ }^{12}$. In regard to criminalization of some behaviours as a positive duty of the state, it is also worth to notice the according to the ECtHR, the procedural obligation of Article 2 in the context of health care requires state to set up an effective and independent judicial system so that the cause of death of patients in the care of the medical profession. It means that in some exceptional situations, where the fault attributable to the health-care providers went beyond a mere error or medical negligence, the compliance with the procedural obligation must include recourse to criminal law. In all other cases where the infringement of the right to life or to personal integrity is not caused intentionally however, the procedural obligation imposed by Article 2 to set up an effective and independent judicial system does not necessarily require the provision of a criminal law remedy ${ }^{13}$.

The next area in which ECtHR requires a recourse to criminal law is cruel and inhuman treatment, especially when children are the victims of such actions ${ }^{14}$. Serious acts such as rape and sexual abuse of children, where fundamental values and essential aspects of private life are at stake, it falls upon the states to ensure

11 See e.g. Verein gegen Tierfabriken Schweiz (VGT) v. Switzerland, ECtHR, (2009, no. 32772/02).

12 See inter alia L.C.B. v. The United Kingdom, ECtHR, (1998, no. 23413/94); Osman v. The United Kingdom, ECtHR, (1998, no. 23452/94).

13 See Lopes de Sousa Fernandes v. Portugal, ECtHR (2017, no. 56080/13).

14 See $A$. v. The United Kingdom, 23 September 1998, (ECtHR, 1998, no. 25599/94); Z and Others v. The United Kingdom, ECtHR, (2001 no. 29392/95). 
that efficient criminal-law provisions are in place. Such need for was emphasized by the ECtHR in the context of the sexual exploitation of minors, where the ECtHR pointed out, that the lack of criminalization of sexual offers made to a mentally handicapped minor meant that the state failed to fulfil its positive obligation to protect the rights of victims under Article 8 of the ECHR ${ }^{15}$. According to the ECtHR, the measures applied by the state to protect children against acts of violence should be effective and include reasonable steps to prevent ill-treatment of which the authorities had, or ought to have had, knowledge and effective deterrence against such serious breaches of personal integrity.

It needs to be emphasized that the ECtHR does not consider it appropriate to assess what specific types of offences the states-parties should define in their legal systems. In respect of less serious acts between individuals, which may violate psychological integrity, the obligation of the State under Article 8 to maintain and apply in practice an adequate legal framework affording protection does not always require that an efficient criminal-law provision be in place. In one of the cases heard by the ECtHR, domestic law did not provide for criminal liability for filming a naked child for pornographic purposes. Despite this, the ECtHR pointed out, that recourse to the criminal law was not necessarily the only way that the respondent State could fulfil its obligations under Article 8 of the ECHR. The violation of the ECHR was in casu determined by the lack of adequate parallel civil law remedies.

The requirement of effective protection (Article 3 and Article of the 8 ECHR), by criminal law measures, was also highlighted by the ECtHR in the case of preventing rape and sexual abuse. The ECtHR pointed out that the positive obligations of the member states must be seen as requiring punishment and effective prosecution of any sexual act that takes place without the consent of the party, including cases where the victim has not physically resisted ${ }^{16}$. Thus, instruments of criminal law can also serve to protect freedom and private life ${ }^{17}$.

Another example of positive obligation realized by the means of criminal law is the act of servitude, examined by the ECtHR in the case Silidian v. France ${ }^{18}$. In that judgment the Court pointed out that France violated Article 4 of the ECHR due to the lack of criminalization of behaviour consisting in servitude.

Therefore, it can be said that the obligation to recourse to criminal law measures applies to the most serious violations of human dignity or fundamental

15 See $X$ and $Y$ v. Netherlands, ECtHR, (1985 no. 8978/80); cf. O'Keeffe v. Ireland, ECtHR, (2014, no. 35810/09).

16 See M.C. v. Bulgaria, ECtHR (2003, no. 39272/98).

17 See Phinikaridou v. Cyprus, ECtHR (2007, no. 23890/02).

18 See Siliadin v. France, ECtHR, (2005, no. 73316/01). 
values. In other words, the role of criminal law in relation to ECHR guarantees is to ensure that they are respected in cases of drastic violations of individual rights. In addition, the ECtHR identified situations in which the use of criminal law instruments should be assessed as disproportionate, and thus interfering with the rights and freedoms guaranteed by the ECHR to an unacceptable extent. The ECtHR did so in a case concerning the criminalization of behaviour defined in domestic law as "promotion of homosexuality and non-traditional sexual relations among minors" 19 .

As it was mentioned above, the principle of proportionality must be taken into consideration when it comes to transform previously legal human behaviours into crimes. The immanent relation between principle of proportionality and criminalization is pointed out under the ECHR, as well as under the Charter. In relation to EU law, it is however, the relatively "soft" principles such as the socalled ultimum remedium notion are underlined. It is noticed, that the principle of proportionality despite its importance for the public debate, is not able to provide unambiguous answer to the question of the limits of criminalization in the scope of EU law (van Kempen, Bemelmans, 2018: 251).

Taking the above into account, it should be stated that the analysed acts of international law do not express a uniform principle for criminalization. The margin of appreciation is left to the states. However, this margin not identical in each case but will vary according to the context. Relevant factors include the nature of the Convention right in issue, its importance for the individual and the nature of the activities concerned ${ }^{20}$. As a rule, it is the national legislator who decides whether a given behaviour should be sanctioned as serious offences (crimes), lesser offences (delicts) and petty offences (contraventions), administrative delicts, or whether it will be sufficient to recourse to measures granted by the civil law. It is worth emphasizing that the ECtHR accepts the possibility of transforming serious offences into petty offenses or to remove offences from the criminal sphere and classify them as "regulatory" offences (administrative delicts).

\section{The principle of guilt}

Pursuant to the Article $1 \S 3$ of the polish Penal Code from 1997 the perpetrator does not commit a crime if they cannot be ascribed guilt during the act. The same principle is stated in the Article $1 \S 2$ of the polish Petty Offences Code.

19 See Bayev and Others v. Russia, ECtHR, (2017, no. 67667/09, 44092/12, 56717/12).

20 See Laskey, Jaggard and Brown v. the United Kingdom, ECtHR, (1997, no. 21627/93; 21628/93; 21974/93). 
Above mentioned acts constitute a clear declaration of recognizing guilt as a necessary condition of an offence and petty offence. It is pointed out that he occurrence of the principle of guilt in penal law is connected with two functions performed by guilt. These are, above all, the legitimating function which gives the basis for the state's reaction in the form of punishment for a prohibited act as well as the limiting function - in the form of establishing the punishment on the basis of the degree of guilt (Komandowska, 2014-2015: 115).

The analysed acts of international law do not express directly the principle of guilt in a way the polish legislator does it. Therefore, it is correct to conclude that the ECHR does not stipulate the principle of guilt as the basis of criminal liability.

The above mentioned does not mean, however, that the issue of attributing guilt to the perpetrator of a prohibited act is not raised in complaints about violation of the ECHR and thus remains beyond the scope of the ECtHR's interest. The normative grounds for the decisions of the ECtHR in the discussed scope are Art. 6 section 2 and art. 7 section 1 of the ECHR. The first of these provisions expresses the principle of the presumption of innocence, stipulating that everyone charged with a criminal offence shall be presumed innocent until proved guilty according to law. The second provision expresses the so-called nullum crimen, nulla poena sine lege principle, according to which no one shall be held guilty of any criminal offence on account of any act or omission which did not constitute a criminal offence under national or international law at the time when it was committed. Despite the fact that both provisions cited above use the concept of guilt, the principle of guilt as the basis of criminal liability, cannot be directly inferred from either. Although the Article 6 ECHR expresses a procedural guarantee and the Article 7 of the relates to the validity of criminal law provisions, ECtHR formulates on their basis general postulates that can be considered as regarding the principle of guilt. It needs to be emphasized however, that in analysed case we are not dealing with a coherent model. The views of the ECtHR concern rather individual issues, which makes them hard to synthetize.

For example, in the case of A.P., M.P. and T.P. v. Switzerland tax authorities-initiated proceedings against the applicants - heirs of the late company owner - for recovery of the unpaid taxes and at the same time-imposed fines for tax evasion. The applicants resisted the imposition of the fines, claiming that they were innocent of the tax offence committed by the late owner. In the opinion of ECtHR inheritance of the guilt of the dead is not compatible with the standards of criminal justice in a society governed by the rule of law $^{21}$. Such rule is required by the presumption of innocence stipulated in the Article 6 section 2 of the ECHR.

21 See A.P, M.P. and T.P. v. Switzerland, ECtHR (1997 no. 19958/92). 
It is worth to notice that despite the assess of a cited judgment as a right attempt to fill the gap in the substantive regulation of guilt in the ECHR, some Authors raises serious concerns about referring to the Article 6 of the ECHR as a source of such principle (See Ruggeri ed., 2015: 55 with the references cited therein ).

On the other hand, in the case of Varvara v. Italy the ECtHR referred to the Article 7 of the ECHR and principle of legality. According to the Court, prohibition of punishing a person for an offence committed by another is a consequence of cardinal importance that flows from the principle of legality in criminal law ${ }^{22}$. Also, this view is criticized by some Authors (van Kempen, Bemelmans, 2018: 254).

Third group of remarks worth mentioning regards the so-called strict liability principle. According to the ECtHR states remain free to apply the criminal law to any act which is not carried out in the normal exercise of one of the rights protected under the ECHR and, accordingly, to define the constituent elements of the resulting offence. The ECtHR does not conceive it as its role under Article 6 section 1 or 2 to dictate the content of domestic criminal law, including whether or not a blameworthy state of mind should be one of the elements of the offence or whether there should be any particular defence available to the accused ${ }^{23}$. In the case cited above, the justification for the wide margin of freedom recognized by the ECtHR in defining the limits and principles of criminal liability was the importance of the protected good, e.g., protection of sexual freedom; protection of minors from abuse. A similar view is expressed in the legal doctrine, where it is pointed that strict liability does not violate a limine the ECHR (See Sullivan, 2005: 217-218). However, it has to be noted that according to science of law the concept of strict liability is not the same as an absolute liability. It is pointed out that strict liability means responsibility despite the perpetrator's lack of awareness of that he is committing the prohibited act in the circumstances when perpetrator was not deprived of the possibility of making arrangements to exclude committing a prohibited act, or that it could not be expected of him. The above-mentioned places the strict liability close to a crime committed as a result of negligence (See Hryniewicz-Lach, 2015: 210; cf Duff, 2005: 125). Some Authors, however, states that the concept of strict liability is incompatible with the principle of guilt and adequate liberal standards (Vanacore, 2015: 844).

The principle of guilt leads to subjectivization of penal law, reducing the responsibility of the perpetrator to the consequences that the former has been able to foreseen (See Komandowska, 2015: 115). Despite the lack of such direct

22 See Varvara v. Italy, ECtHR, (2013, no. 17475/09).

23 See G. v. the United Kingdom, ECtHR, (2011 no. 37334/08). 
provision in the ECHR, the foreseeability of committing prohibited act is taken by into consideration the ECtHR when analysing the criminal liability. According to the ECtHR, imposing penalties within the meaning of Article 7 of the ECHR, requires that these consequences have to be foreseeable. A measure can only be regarded as a penalty within the meaning of Article 7, where an element of personal liability on the part of the offender has been proven. In other words, imposing criminal measures in the absence of a mental link disclosing an element of liability in the conduct of perpetrator is prohibited ${ }^{24}$.

It also has to be mentioned about the relation between principle of guilt and idea of accountability in criminal law. As the ECtHR points out, presumptions of fact or of law operate in every legal system. It raises a question about admissibility of such presumptions in the scope of ECHR. In the case of Salabiaku v. France man accused of possession of drugs defended himself that he was unaware of the presence of drugs in the parcel he has collected earlier. According to the ECtHR, the ECHR does not prohibit such presumptions in principle. Article 6 section 2 of the ECHR does require however states to confine such presumptions within reasonable limits which take into account the importance of what is at stake and maintain the rights of the defence ${ }^{25}$.

Also under the EU law, it is difficult to speak of the absolute application of the principle of guilt, since such principle is not expressed in the acts of EU law. However, the Charter stipulates the presumption of innocence (Article 48 section 1) and the principle of proportionality (Article 49 section 1). According to the science of law, the assess of the proportionality of the sanctions should comply three indicators: the importance of the protected interest (good), the amount of the damage and the degree of guilt (Wróbel, 2013: 1279-1281). The last of these criteria is recognized and applied by the EU courts. The former Court of First Instance pointed out that, according to the guilt principle (nulla poena sine culpa), recognized by the criminal law systems of the Member States, by Article 6 section 2 of the ECHR and by the Article 49 section 3 of the Charter, the penalty imposed must be proportionate to the guilt of the undertaking to which it applies ${ }^{26}$.

It is also pointed out that the principle of guilt enjoys the status of a fundamental right which is common to the constitutional traditions of the EU Member States. Although this principle is not expressly mentioned in the Charter it is the

24 See G.I.E.M. S.r.l. and Others v. Italy, ECtHR (2018, no. 1828/06, 34163/07 and 19029/11); cf. Sud Fondi S.r.l. and Others v. Italy, ECtHR, (2012, no. 75909/01); Varvara v. Italy, ECtHR (2013, no. 17475/09).

25 See Salabiaku v. France, ECtHR, (1998, no. 10519/83).

26 See T-279/02 Degussa AG v Commission of the European Communities, 5 April 2006 r., CFI. 
necessary precondition for the presumption of innocence. The principle of nulla poena sine culpa may therefore be considered to be contained implicitly in Article 48 section 1 of the Charter ${ }^{27}$.

In its judgements the CJEU accepts also the use of administrative sanctions imposed on the basis of objective liability. According to the case-law of the CJEU, system of strict liability is not, in itself, disproportionate to the objectives pursued, if that system is such as to encourage the persons concerned to comply with the provisions of a regulation and where the objective pursued is a matter of public interest which may justify the introduction of such a system ${ }^{28}$. However, in such cases the penalty must not be disproportionate to the gravity of the infringement (Klip, 2016: 221). ${ }^{29}$

The analysed case law does makes it hard to point out general conclusions in regard to the principle of guilt. On the other hand, there are certain guidelines concerning guilt that the national legislator must follow.

Firstly, it is unacceptable under the ECHR to adopt provisions allowing for the imposition of criminal liability for act perpetrator did not commit.

Secondly, state has to ensure that when recognition of the actual content of a criminal prohibition and adapting one's own actions to it is impossible due to justified and unavoidable circumstances not attributable to the addressee of the prohibition, no criminal liability will be imposed.

Thirdly, as the CJEU points out, even if administrative fines are imposed on the basis of objective liability, the legislator is obliged to respect the principle of proportionality and allow the court to take the degree of guilt into account when imposing a sanction.

\section{The ne bis in idem principle}

The principle of ne bis in idem is one of the guiding principles of criminal law and, in the wide sense, means the prohibition of instituting and conducting criminal proceedings concerning the same person and the same criminal offence (procedural aspect) and the prohibition of double (multiple) punishment in criminal cases concerning the same person and the same offense.

Analysed principle is stipulated in both, the ECHR and the Charter, as well as it is proclaimed by the Covenant. Pursuant to the Article 4 section 1 to the

27 Opinion of Advocate General Kokott, 28 February 2013, Case C-681/11.

28 See C-443/13 Ute Reindl v Bezirkshauptmannschaft Innsbruck, 2014, CJEU.

29 See C-262/99 Paraskevas Louloudakis v Elliniko Dimosio, 2001 CJEU. 
Protocol 7 to the ECHR, no one shall be liable to be tried or punished again in criminal proceedings under the jurisdiction of the same State for an offence for which he has already been finally acquitted or convicted in accordance with the law and penal procedure of that State $^{30}$.

Article 50 of the Charter stated that, no one shall be liable to be tried or punished again in criminal proceedings for an offence for which he or she has already been finally acquitted or convicted within the Union in accordance with the law. It has to be also mentioned that, pursuant to the Article 54 of the Convention implementing the Schengen Agreement of 14 June 1985 between the Governments of the States of the Benelux Economic Union, the Federal Republic of Germany and the French Republic on the gradual abolition of checks at their common borders (CISA), a person whose trial has been finally disposed of in one Contracting Party may not be prosecuted in another Contracting Party for the same acts provided that, if a penalty has been imposed, it has been enforced, is actually in the process of being enforced or can no longer be enforced under the laws of the sentencing Contracting Party.

It is then clear that under the CISA the ne bis in idem principle is limited to the cases when the penalty has been imposed, it has been enforced, is actually in the process of being enforced, while the Charter does not require such condition to be fulfilled. According to the explanations to Charter, the very limited exceptions in the CISA permitting the Member States to derogate from the non bis in idem rule are covered by the horizontal clause in Article 52 section 1 of the Charter concerning limitations. CJEU confirmed the accordance of the Article 54 of CISA with Article 50 of the Charter and pointed out that the execution condition laid down in Article 54 CISA does not call into question the ne bis in idem principle as such. That condition is intended, inter alia, to avoid a situation in which a person definitively convicted and sentenced in one Contracting State can no longer be prosecuted for the same acts in another Contracting State and therefore ultimately remains unpunished if the first State did not execute the sentence imposed ${ }^{31}$.

Article 14 section 7 of the Covenant stipulates that, no one shall be liable to be tried or punished again for an offence for which he has already been finally convicted or acquitted in accordance with the law and penal procedure of each country.

The jurisprudence of ECtHR presented different views on fundamental elements of the ne bis in idem principle until the case of Zolotukhin v. Russia, where

30 Cf. Article 7 of the Convention on the Protection of the European Communities' Financial Interests, OJ C 316, 27.11.1995, p. 49-57 and Article 10 section 1 of the Convention on the fight against corruption involving EU officials or officials of EU countries, OJ C 195, 25.6.1997, p. 2-11.

31 See C-129/14 Zoran Spasic, 2014, CJEU. 
the ECtHR harmonized its previous views and pointed out what does idem in analysed rule mean. According to the ECtHR, the Article 4 of Protocol No. 7 must be understood as prohibiting the prosecution or trial of a second "offence" in so far as it arises from identical facts or facts which are substantially the same ${ }^{32}$..

With regard to the relation between administrative and criminal proceedings the case of the ECtHR summarized and harmonized its views in the case of A.B. v. Norway. The ECtHR pointed out that the surest manner of ensuring compliance with Article 4 of Protocol No. 7 is the provision, at some appropriate stage, of a single-track procedure enabling the parallel strands of legal regulation of the activity concerned to be brought together, so that the different needs of society in responding to the offence can be addressed within the framework of a single process. Nonetheless, Article 4 of Protocol No. 7 does not exclude the conduct of dual proceedings, even to their term, provided that certain conditions are fulfilled. In particular that there is no duplication of trial or punishment (bis) as proscribed by Article 4 of Protocol No. 7, the respondent State must demonstrate convincingly that the dual proceedings in question have been "sufficiently closely connected in substance and in time". In other words, it must be shown that they have been combined in an integrated manner so as to form a coherent whole. This implies not only that the purposes pursued and the means used to achieve them should in essence be complementary and linked in time, but also that the possible consequences of organizing the legal treatment of the conduct concerned in such a manner should be proportionate and foreseeable for the persons affected ${ }^{33}$. The abovementioned view is also supported by $\mathrm{CJEU}^{34}$.

With regard to the CJEU jurisprudence, it is worth to mention that in its case-law CJEU adopted special criterion that arguably delimit the scope of the principle of ne bis in idem in the context of competition law ${ }^{35}$. As a matter of EU law, the sameness of an offence is generally to be determined on the basis of a two-fold criterion: the facts and the offender must be the same. However, in the competition law also the legal interest protected matters. In other words, the CJEU set out the principle that the principle of ne bis in idem may only be relied upon where there is identity of facts, offender and the legal interest protected.

The presented view cannot be accepted. I agree with the opinion that the principle of ne bis in idem, as enshrined in Article 50 of the Charter, should be

32 See Zolotukhin v. Russia, ECtHR (2009, no. 14939/03).

33 See $A$ and $B$ v. Norway, ECtHR, (2016, no. 24130/11 and 29758/11).

34 See C-524/15 Luca Menci, 20 March 2018 r., CJEU.

35 See C 204/00 P, C 205/00 P, C 211/00 P, C 213/00 P, C 217/00 P and C 219/00 Aalborg Portland et al v. EC, , 7 January 2004, CJEU; C 17/10 Toshiba Corporation et al, 14 February 2012, CJEU. 
interpreted uniformly in all areas of EU law, having due regard to the requirements of the case-law of the ECtHR. The special features of completion law do not constitute sufficient reasons to limit the protection afforded by the Charter in the field of competition law ${ }^{36}$.

\section{The principle of legality (nullum crimen sine lege, nulla poena sine lege)}

Article 7 section 1 of the ECHR stipulates that, no one shall be held guilty of any criminal offence on account of any act or omission which did not constitute a criminal offence under national or international law at the time when it was committed. Nor shall a heavier penalty be imposed than the one that was applicable at the time the criminal offence was committed".

From these principles it follows that an offence must be precisely defined by the law. This requirement is satisfied if the individual can know from the wording of the relevant provision and, if need be, with the assistance of the courts' interpretation of it, what acts and omissions will make him criminally liable ${ }^{37}$.

Similar rules are derived from the provisions of the Charter and the Covenant, since the principle of legality and proportionality is provided by the Article 49 section 1 of the Charter. The principle of the legality of criminal offences and penalties (nullum crimen, nullum poena sine lege), as enshrined in particular in Article 49 section 1 of the Charter, requires that European Union rules define offences and penalties clearly. Moreover, the principle of legal certainty requires that such rules enable those concerned to know precisely the extent of the obligations which are imposed on them, and that those persons must be able to ascertain unequivocally what their rights and obligations are and take steps accordingly ${ }^{38}$.

The wording of Article 7 section 1 of the ECHR, indicates that the startingpoint in any assessment of the existence of a "penalty" is whether the measure in question is imposed following a decision that a person is guilty of a criminal offence. The "criminal offence" concept has an autonomous meaning, like "criminal charge" in Article 6 of the ECHR. The three criteria set out in the case of Engel

36 Opinion of Advocate General Wahl, 29 November 2018, Case C-617/17.

37 See inter alia S.W. v. The United Kingdom, ECtHR, (1995, no. 20166/92); C.R. v. The United Kingdom, 22 November 1995, ECtHR, No. 20190/92; Vasiliauskas v. Lithuania, ECtHR, (2015, no. $35343 / 05)$.

38 See C 352/09 P ThyssenKrupp Nirosta GmbH v European Commission, 29 March 2011, CJEU; Wieruszewski ed., 2012: 340. 
and Others v. the Netherlands for assessing whether a charge is "criminal" within the meaning of Article 6 must also be applied to Article $7^{39}$.

The term "law" under the Article 7 alludes to the very same concept as that to which the ECHR refers elsewhere when using that term, a concept which comprises written as well as unwritten law. It means that the word "law" covers not only statutory but also common law ${ }^{40}$. What is important, the ECtHR understands the term "law" in its "substantive" sense, not its "formal" one. The above-mentioned means "written law", encompassing enactments of lower rank than and regulatory measures taken by professional regulatory bodies under independent rule-making powers delegated to them by parliament and unwritten law (including judge-made "law"). Concluding, it has to be emphasized that according to ECtHR, the "law" is the provision in force as the competent courts have interpreted $\mathrm{it}^{41}$.

Article 7 of the ECHR and the concept of "law" used therein implies qualitative requirements, notably those of accessibility (whether the criminal "law" on which the impugned conviction was based was sufficiently accessible to the applicant, had been made public) and foreseeability. Though in any law system there is an inevitable element of judicial interpretation, Article 7 of the ECHR cannot be read as outlawing the gradual clarification of the rules of criminal liability through judicial interpretation a casu ad casum, provided that the resultant development is consistent with the essence of the offence and could reasonably be foreseen ${ }^{42}$.

Article 7 of the ECHT express directly only the lex severior retro non agit principle. However according to the ECtHR Article $7 \S 1$ of the ECHR guarantees not only the principle of non-retrospectiveness of more stringent criminal laws but also, and implicitly, the principle of retrospectiveness of the more lenient criminal law (the lex mitior agit principle). That principle is embodied in the rule that where there are differences between the criminal law in force at the time of the commission of the offence and subsequent criminal laws enacted before a final judgment is rendered, the courts must apply the law whose provisions are most favourable to the defendant ${ }^{43}$.

39 Guide on Article 7 of the European Convention on Human Rights, updated on 31 December 2020, https://www.echr.coe.int/Documents/Guide_Art_7_ENG.pdf, s. 6.

40 See e.g. Tolstoy Miloslavsky v. The United Kingdom, ECtHR, (1995, no. 18139/91); Streletz, Kessler and Krenz v. Germany, ECtHR, (2001, no. 34044/96, 35532/97, 44801/98); Kafkaris v. Cyprus, ECtHR, (2008, no. 21906/04); Navalnyye v. Russia, ECtHR, (2017, no. 101/15).

41 See Şahin v. Turkey, ECtHR, (2004, no. 44774/98).

42 See e.g. Kokkinakis v. Greece, ECtHR,(1993, No. 14307/88); Del Río Prada v. Spain, ECtHR, (2013, no. 42750/09).

43 See Scoppola v. Italy No. 2, ECtHR, (2009, no.10249/03). 
The principle of retrospectiveness of the more lenient criminal law is directly expressed in the third sentence of the Article 49 section 1 of the Charter and in the third sentence of the Article 15 section 1 of the Covenant.

\section{The non-binding regulations concerning petty offences law}

It is also worth to mention that recommendations in regard to analysed issue were presented in non-binding legal documents. The Resolution of the Congresses of the International Association of Penal Law adopted on the Fourteenth International Congress of Penal Law (Vienna, 2-7 October 1989) focused on the legal and practical problems posed by the difference between criminal law and administrative penal law ${ }^{44}$. According to the Resolution administrative penal law resembles criminal law in that it provides for the imposition of retributive sanctions. This similarity requires application of the basic principles of criminal law and of due process to the field of administrative penal law. The Congress proposed following principles concerning substantive law.

Firstly, the definitions of administrative penal infractions as well as of administrative penal sanctions should be fixed in accordance with the principle of legality and the lines between criminal offenses and administrative penal infractions should be drawn, with sufficient clarity.

Secondly, Administrative penal responsibility of physical persons should be based on personal fault (intent or negligence).

Thirdly, corporate liability should be imposed as an administrative liability.

Fourthly, the defenses of justification and excuse recognized in criminal law, including unavoidable mistake of law and extenuating circumstances, should likewise be available in administrative penal law.

Administrative sanctions, understood as penalties (fine or any punitive measures) imposed on persons on account of conduct contrary to the applicable rules, were also the subject of Recommendation No. R (91)1 of the Council of Europe Committee of Ministers ${ }^{45}$. As for the substantive law, the Committee suggests to adopt following guarantees: 1) sanctions and the rules of their imposition should be laid down by the law; 2) no administrative sanction may be imposed an account of an act which, at time when it was committed did not constitute conduct contrary to

44 See http://www.penal.org/sites/default/files/RIDP86\%201-2\%202015\%20EN.pdf, pp. $351 \mathrm{ff}$.

45 Adopted by the Committee of Ministers on 13 February 1991 at the $452^{\text {nd }}$ meeting of the Ministers' Deputies. 
applicable rules - the principles of lex mitior retro agit and lex beningior agit should apply; 3) a person may not be administratively penalized twice for the same act, on the basis of rules of law or rules protecting the same interest.

\section{Summary}

In authors opinion there is no precise model of substantive petty offences law in international law. However, some standards can be deduced from analysed legal acts and judgments.

Firstly, it has to be pointed out, that, in principle national, legislator is entitled to choose the form of reaction he considers best from the point of view of protecting human rights and social interest, the gravity of endangerment or harm, degree of guilt etc. Petty offences can be therefore replaced in the legal system with crimes (as well as crimes can be converted into petty offences) or administrative (regulatory) delicts. However, in some cases the character of chosen measure should imply further regulations. For example, the view is presented, that "sanctions for administrative penal infractions should be reasonable and proportionate to the gravity of the infraction and the personal circumstances of the offender. Deprivation and restriction of personal liberty should not be available as a primary sanction or as an enforcement measure" ${ }^{46}$.

Secondly there are some rules common to all of abovementioned sanctions. However, the ECtHR allows lowering of some procedural standards (e.g., dispensing an oral hearing) in cases not belonging to the traditional categories of criminal law such as proceedings concerning traffic offences where the issues at stake were of a rather technical nature, or even relating to a factual matter, and where the accused had been given an adequate opportunity to put forward his case in writing and to challenge the evidence against him ${ }^{47}$. When assessing the scope of application of guarantees under Article 6 of the ECHR to administrative sanctions, the ECtHR indicated that the differences between criminal law sensu stricto and administrative law may not exempt from the obligation to apply the guarantees provided for in this provision. However, such differences may justify the different scope of these guarantees ${ }^{48}$.

The crucial issue is whether the discussed differentiation should relate to both procedural guarantees and those that can be located in the sphere of substantive

46 See http://www.penal.org/sites/default/files/RIDP86\%201-2\%202015\%20EN.pdf, pp. $351 \mathrm{ff}$.

47 See Marčan v. Croatia, ECtHR (2014, no. 40820/12).

48 See A. Menarini Diagnostics S.R.L. v Italy, ECtHR (2101, no. 43509/08) 
law. It seems that it cannot be ruled out that also with regard to the substantive law of offenses, it would be permissible to vary the level of implementation of the conventional guarantees. Although the Article 6 of the ECHR sets out the principles of a fair trial, it should be noted that in the previously mentioned case of Salabiaku v. France, the ECtHR resolved issues related to the principles of assigning guilt.

Considering the lack of clear declarations of the ECtHR with regard to substantive law guarantees, it should be concluded that the type of liability with which the imposition of a "criminal" sanction is connected should not affect the level of compliance with the convention standards. Such conclusion is supported by the guarantee function of criminal law, which should be implemented in all cases where the legislator considers introducing a type of prohibited act and providing it with an appropriate sanction.

\section{Bibliography}

- Błachnio-Parzych, A. (2016) Zbieg odpowiedzialności karnej i administracyjno-karnej jako zbieg reżimów odpowiedzialności represyjnej. Warsaw: Wolters Kluwer Polska;

- Christoffersen, J. (2009), Fair Balance: Proportionality, Subsidiarity and Primality in the European ECHR on Human Rights. Leiden, Boston: Brill.

- Duff R.A. (2005) Strict Liability, Legal Presumptions, and the Presumption of Innocence. In: A.P. Simester (ed.) Appraising Strict Liability. Oxford: Oxford University Press. DOI:10.1093/acprof:oso/9780199278510.003.0006

- Harris, D., O’Boyle, M., Bates, E., Buckley, C. (2009), Harris, O'Boyle \& Warbrick: Law of the European ECHR on Human Rights. Oxford: Oxford University Press.

- Hryniewicz-Lach, E. (2015) Kara kryminalna w świetle Konstytucji RP. Warsaw: C. H. Beck.

- Klip, A. (2016) European Criminal Law. An Integrative Approach. Cambridge-Antwerp-Portland: Intersentia.

- Komandowska A. (2014-2015), The principles of guilt - remarks on the background of the polish penal code. Roczniki Wydziatu Nauk Prawnych i Ekonomicznych KUL 1, pp. 115-125.

- Ruggeri, S. ed. (2015) Human Rights in European Criminal Law. New Developments in European Legislation and Case Law after the Lisbon Treaty. Heidelberg: Springer.

- Sullivan, G.R. (2005) Strict Liability for Criminal Offences in England and Wales Following Incorporation into English Law of the European ECHR on 
Human Rights. In: A.P. Simester (ed.) Appraising Strict Liability, Oxford: Oxford University Press. DOI:10.1093/acprof:oso/9780199278510.003.0008

- Tulkens, F. (2011) The Paradoxical Relationship between Criminal Law and Human Rights, Journal of International Criminal Justice, 9(3), pp 577-595. https://doi.org/10.1093/jicj/mqr028

- Van Kempen, P.M., Bemelmans J. (2018) EU Protection of the Substantive Criminal Law Principles of Guilt and Ne Bis in Idem Under the Charter of Fundamental Rights: Underdevelopment and Overdevelopment in an Incomplete Criminal Justice Framework. New Journal of European Criminal Law, 9(2), pp. 247-264. https://doi.org/10.1177/2032284418778146

- Vanacore, G. (2015) Legality, Culpability and Dogmatik: A Dialogue between the ECtHR Comparative and International Criminal Law. International Criminal Law Review 15(5), pp. 823-860. https://doi.org/10.1163/1571812301506001

- Wieruszewski, R, ed. (2012) Międzynarodowy pakt praw obywatelskich (osobistych) i politycznych. Warsaw: C.H. Beck.

- Wróbel, A. ed. (2013) Karta Praw Podstawowych Unii Europejskiej. Komentarz, Warsaw: C.H. Beck.

Legal references

- Convention for the Protection of Human Rights and Fundamental Freedoms, adopted 4 November 1950, entered into force 3 September 1953; ETS 5, 213 UNTS 222.

- International Covenant on Civil and Political Rights, adopted 16 December 1966, entered into force 23 March 1976; 999 UNTS 171

- The Charter of Fundamental Rights of the European Union (adopted 7 December 2000, entered into force 1 December 2009; OJ C 326, 26.10.2012, p. 391-407;

- Convention on the Protection of the European Communities' Financial Interests, entered into force 17 October 2002, OJ C 316, 27.11.1995;

- Convention on the fight against corruption involving EU officials or officials of EU countries, entered into force on 28 September 2005, OJ C 195, 25.6.1997.

\section{Internet resources:}

- Guide on Article 7 of the European Convention on Human Rights, updated on 31 December 2020, available at: https://www.echr.coe.int/Documents/ Guide_Art_7_ENG.pdf; date of access: 29 November 2021 
- Recommendation No. R (91)1 of the Committee of Ministers of Member States on administrative sanctions (adopted by the Committee of Ministers on 13 February 1991 at the $452^{\text {nd }}$ meeting of the Ministers' Deputies) available at: https://rm.coe.int/16804fc94c; date of access: 29 November 2021

- Resolutions of the Congresses of the International Association of Penal Law (1926 - 2014), available at: http://www.penal.org/sites/default/files/ RIDP86\%201-2\%202015\%20EN.pdf, pp. 351 ff; date of access: 29 November 2021

Case law:

- A and B v. Norway, ECtHR, (2016, no. 24130/11 and 29758/11);

- A. P, M.P. and T.P. v. Switzerland, ECtHR (1997 no. 19958/92);

- A. v. The United Kingdom, 23 September 1998, (ECtHR, 1998, no. 25599/94);

- Bayev and Others v. Russia, ECtHR, (2017, no. 67667/09, 44092/12, 56717/12);

- Bendenoun v. France, ECtHR (1994, no. 12547/86);

- C 204/00 P, C 205/00 P, C 211/00 P, C 213/00 P, C 217/00 P and C 219/00 Aalborg Portland et al v. EC, , 7 January 2004, CJEU;

- C 352/09 P ThyssenKrupp Nirosta GmbH v European Commission, 29 March 2011, CJEU;

- C.R. v. The United Kingdom, 22 November 1995, ECtHR, No. 20190/92;

- C-129/14 Zoran Spasic, 2014, CJEU;

- C-17/10, Toshiba Corporation et al v. Úřad pro ochranu hospodářské soutěže, CJEU; (2012, no. C-17/10) Bonda, CJEU, (2012, no. C-489/10);

- C-262/99 Paraskevas Louloudakis v Elliniko Dimosio, 2001 CJEU;

- C-443/13 Ute Reindl v Bezirkshauptmannschaft Innsbruck, 2014, CJEU;

- C-524/15 Luca Menci, 20 March 2018 r., CJEU;

- Del Río Prada v. Spain, ECtHR, (2013, no. 42750/09);

- Engel and Others v. Netherlands, (1976, no. 5100/71, 5101/71, 5102/71, 5354/72, 5370/72);

- Ezeh and Connors v. The United Kingdom, ECtHR (1997, no. 39665/98, 40086/98).

- G. v. the United Kingdom, ECtHR, (2011 no. 37334/08);

- G.I.E.M. S.r.l. and Others v. Italy, ECtHR (2018, no. 1828/06, 34163/07 and 19029/11);

- Grande Stevens and Others v. Italy, ECtHR (2014, no. 8640/10);

- Janosevic v. Sweden, ECtHR (2002, no. 34619/97);

- Kafkaris v. Cyprus, ECtHR, (2008, no. 21906/04); 
- Kokkinakis v. Greece, ECtHR,(1993, No. 14307/88);

- L.C.B. v. The United Kingdom, ECtHR, (1998, no. 23413/94);

- Laskey, Jaggard and Brown v. the United Kingdom, ECtHR, (1997, no. 21627/93; 21628/93; 21974/93);

- Lauko v. Slovakia, ECtHR (1998, no. 26138/95);

- Lopes de Sousa Fernandes v. Portugal, ECtHR (2017, no. 56080/13).

- Lutz v. Germany, ECtHR (1987, no. 9912/82);

- M.C. v. Bulgaria, ECtHR (2003, no. 39272/98);

- Malige v. France, ECtHR, (1998, no. 7812/95);

- Marčan v. Croatia, ECtHR (2014, no. 40820/12);

- Menarini Diagnostics S.R.L. v Italy, ECtHR (2101, no. 43509/08);

- Navalnyye v. Russia, ECtHR, (2017, no. 101/15);

- O'Keeffe v. Ireland, ECtHR, (2014, no. 35810/09).

- Opinion of Advocate General Kokott, 28 February 2013, Case C-681/11.

- Opinion of Advocate General Wahl, 29 November 2018, Case C-617/17

- Osman v. The United Kingdom, ECtHR, (1998, no. 23452/94)

- Ozturk v. Germany, ECtHR (1984, no. 8544/79).

- Phinikaridou v. Cyprus, ECtHR (2007, no. 23890/02).

- Putz v. Austria, ECtHR (1996, no. 18892/91),

- Ravnsborg v. Sweden, ECtHR (1994, no. 14220/88)

- S.W. v. The United Kingdom, ECtHR, (1995, no. 20166/92);

- Şahin v. Turkey, ECtHR, (2004, no. 44774/98).

- Salabiaku v. France, ECtHR, (1998, no. 10519/83).

- Scoppola v. Italy No. 2, ECtHR, (2009, no.10249/03).

- Siliadin v. France, ECtHR, (2005, no. 73316/01).

- Streletz, Kessler and Krenz v. Germany, ECtHR, (2001, no. 34044/96, 35532/97, 44801/98);

- Sud Fondi S.r.l. and Others v. Italy, ECtHR, (2012, no. 75909/01);

- T-279/02 Degussa AGv Commission of the European Communities, 5 April 2006 r., CFI.

- Tolstoy Miloslavsky v. The United Kingdom, ECtHR, (1995, no. 18139/91);

- Varvara v. Italy, ECtHR, (2013, no. 17475/09).

- Vasiliauskas v. Lithuania, ECtHR, (2015, no. 35343/05).

- Verein gegen Tierfabriken Schweiz (VGT) v. Switzerland, ECtHR, (2009, no. 32772/02).

- Weber v. Switzerland, ECtHR, (1990, no.11034/84)

- X and Yv. Netherlands, ECtHR, (1985 no. 8978/80);

- $Z$ and Others v. The United Kingdom, ECtHR, (2001 no. 29392/95)

- Zolotukhin v. Russia, ECtHR (2009, no. 14939/03). 